rule--no instrument has yet been devised which will invariably do this-but should not be too sensitive, or the record of important disturbances may be lost.

(4) The records should be capable of easy and rapid reproduction.

Of the instruments which have been designed or suggested for this purpose, four types are in use to a greater or less extent.

The Wiechert so-called astatic pendulum is an inverted pendulum with a bob weighing more than a ton, kept in position by two springs, and provided with an ingenious system of air-damping of its vibrations. This instrument has been recommended for general use, because its supposed astatic nature is believed to make it record the movement of the soil in an accurate manner; as already pointed out, this condition is immaterial, and, moreover, cannot be completely fulfilled. The instrument is undoubtedly a fine one, and gives valuable records, but its proper place is in an observatory specially devoted to seismology; for general use it is too heavy, requires too much attention, and gives records which are not adapted for ready and rapid reproduction.

The Rebeur-Ehlert instrument is a horizontal pendulum, of the form devised by v. Rebeur-Paschwitz, combined with a recording arrangement devised by Prof. Ehlert. This instrument is an extremely sensitive one, and there seems to be none better for recording small disturbances; in the case of large earthquakes the record is apt to be lost. The record is photographic, and the seismograms are readily reproduced by photography. Its cost of maintenance and too great sensitiveness are the points in which it fails to meet the requirements of an instrument for general adoption.

The so-called Omori pendulum is a horizontal pendulum presenting no special peculiarities, and is a modification, in details only, of a type of instrument in very general use. It fulfils all the first three requirements, being moderate in size, needing little attention, and gives good records, easy of interpretation and measurement. It fails in the fourth requirement only; the record, being taken on smoked paper, is not readily reproduced by photography, and is on too small a scale to obviate the risk of introducing error when copied by tracing.

The fourth type of instrument is the Milne pendulum, a horizontal pendulum with photographic record on a principle quite different from that adopted in any other instrument. This fulfils all the first three requirements, and the fourth too; the seismograms are easily reproduced by contact printing on to the same photographic paper that is used for recording, and the copies are practically as serviceable as the originals. This alone, if the instrument had few other merits, would mean much; but in addition to this I have found its seismograms the most convenient of any for determining the exact time of any point on the record, and had it not been for the general adoption of this type of instrument, and the ease with which its records can be reproduced, a considerable part of what seismological work I have been able to do could not have been attempted. The only improvement I have ever desired to see is an increase in the rate of movement of the recording surface, and this has now been introduced. I have examined and studied hundreds of records of this instrument from different stations; from Victoria, Toronto, Cape Town, Bidston, Paisley, and many other places, its records are consistently good; at a few stations, whether from a defect in the particular instrument, a want of proper adjustment, or, more probably, something in the foundations or the subsoil, its records are less satisfactory, but from none do they seem to be so bad as at Strassburg; having never seen a seismogram of that instrument-it is not easy to get copies from Strassburg-it is impossible to hazard a suggestion of the reason for the failure of the instrument at this station.

No one would wish to see one pattern of instrument adopted to the exclusion of all others, nor has it ever been pretended that the pattern adopted by the organisation which has grown up under the auspices of the British Association is faultless; but for the purpose of securing a large number of records for comparison with each other, and thereby determining the rate of transmission of earthquakes across, through, and around the earth, it is no

NO. I 994, VOL. 77] more faulty than any other pattern, and has one crowning merit which they do not possess. Can it be to this, to the ease of reproduction of its records, which renders unnecessary the centralisation of seismological research, that we must attribute the continuous vilification of a valuable type of instrument? $R$. D. Oldham.

\section{An Early Acoustical Analogue of Michelson's Echelon Grating.}

IN the "CEuvres complètes." of Christiaan Huygens (tome $x .$, p. 57I) occurs the note given below. It was destined for $\mathrm{Ph}$. de la Hire, and of date November, I693. Huygens's remarkable observation and his ingenious explanation of the musical note produced by reflection from a large flight of steps of the noise of a fountain in the park of Chantilly will be read with interest also by those who, though having no ready access to the "Euvres completes," are still concerned with the (reflecting) echelon grating :-

"Je veux adjouter icy au sujet de la réflexion du son une observation assez singulière, que j'ay fait autrefois estant d̀ la belle maison de Chantilly de la Cour où est la statue Equestre on descend avec un degré large de... marches dans le parterre ou il y a une fontaine de celles qu'on appelle gerbe d'eau, qui fait un bruit continuel. Quand on est descendu en bas et qu'on se tient entre le degré et la fontaine on entend du costé du degré une résonance qui a un certain ton de musique qui dure continuellement, tant que la gerbe jette de l'eau. On ne scavoit pas d'où venoit ce son ou en disoit des causes peu vraisemblables ce qui me donna envie d'en chercher une meilleure. Je trouvay bientost qu'il procédoit de la réflexion du bruit de la fontaine contre les pierres du degré. Car comme tout son, ou plustost bruit, réitéré par des intervalles égaux et très petits fait un son de musique, et que la longueur d'un tuyau d'orgue détermine le ton qu'il a par sa longueur par ce que les battements de l'air arrivent également dans les petits intervalles de temps que ses ondoiements emploient à faire deux fois la longueur du tuyau sçavoir quand il est fermé par le bout, ainsi je concevois que chaque bruit tant soit peu distingué qui venoit de la fontaine, estant réflechi contre les marches du degré, devoit arriver à l'oreille de chacune d'autant plus tard qu'elle estoit plus éloignée, et cela par des différences de temps justement égales à celuy que les ondoiements de l'air employent a aller et venir autant qu'estoit la largeur d'une marche. Ayant mesuré cette largueur qui estoit de 17 pouces, je fis un rouleau de papier qui avoit cette longueur, et je trouvai qu'il avoit le mesme ton qu'on entendoit au bas du degré.

"Je trouvay comme j'ay dit que la gerbe n'allant point l'on cessoit d'entendre ce ton. Et aiant eu occasion d'aller

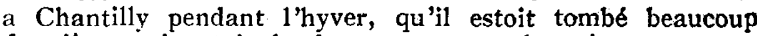
de niège qui ostoit la forme aux marches, je remarquay que on n'entendoit rien quoyque la gerbe allast et fit du bruit à l'ordinaire."

A slight confusion is caused by Huygens's first referring in his note (apparently only drafted) to a closed organpipe and later to an open one. Taking a pouce $=2.7 \mathrm{~cm}$., the depth of the steps becomes $17 \times 2.7=45.9 \mathrm{~cm}$. At $10^{\circ} \mathrm{C}$., the corresponding sound of about 368 vibrations per second would be given by an open pipe of $46 \mathrm{~cm}$.

The effect of gratings on impulsive motion of light is now well understood, thanks to the labours of Lord Rayleigh, Grouy, Schuster, and others. It remains interesting, however, to contrast the opinion concerning the supposed regularity of white light, held by some high authorities before these discussions, with Huygens's statement that the regularity in the nature of the sound which he observed has been impressed upon it bv outside influence.

Amsterdam, January 6.

P. ZEEMAN.

The Inheritance of "Acquired" Characters.

MAY I ask for information upon the interpretation of two sets of facts?

(I) Prof. Henslow states that the garden parsnip " known in the trade as "The Student' was raised from seed of the wild plant by Prof. J. Buckman in 1847 at the Agricultural College, Cirencester," and also that M. 